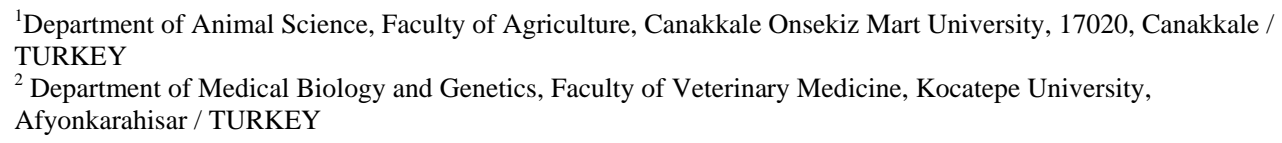

\title{
Effects of Suckling Schedule on Growth Characteristics of Saanen Kids
}

\begin{abstract}
This study was carried out with single-born Saanen kids raised at Uvecik Research and Training Centre of Canakkale Onsekiz Mart University. In the study, the kids were raised according to two suckling program. In the first program, the kids suckled full-udder of their dams for $30 \mathrm{~min}$ at 08.00 and 18.00 . In the second program, the right lob of the udder of the kid's dams was milked by hand, and then the kids were allowed to suckle their dams for $30 \mathrm{~min}$ at 08.00 and 18.00. The kids in the both groups were weaned at 5 weeks of the study. The live weights of the kids of the first and second program were 10963.0 \pm 274.4 and $10384.9 \pm 285.1 \mathrm{~g}(\mathrm{P}>0.05)$ at 5 weeks of the study and $17932.9 \pm 676.3$ and $17482.7 \pm 702.8 \mathrm{~g}(\mathrm{P}>0.05)$ at 12 weeks of the study, respectively. The height at withers and heart girth of the kids of the first and second program were $51.7 \pm 0.9$ and $51.1 \pm 0.9 \mathrm{~cm}$ $(\mathrm{P}>0.05)$, and $61.1 \pm 0.8$ and $58.5 \pm 0.8 \mathrm{~cm}(\mathrm{P} \leq 0.05)$ at 12 weeks of the study, respectively. The live weight increase between 1-5 and 1-12 weeks of the kids of the first and second program were determined as $192.0 \pm 9.5$ and 178.6 $\pm 9.9 \mathrm{~g}(\mathrm{P}>0.05)$, and 160.2 \pm 8.4 and 157.0 $\pm 8.7 \mathrm{~g}(\mathrm{P}>0.05)$, respectively. No significant difference was found between the programs in terms of roughage intake $(\mathrm{P}>0.05)$, concentrate feed intake $(\mathrm{P}>0.05)$, water intake $(\mathrm{P}>0.05)$, rumination $(\mathrm{P}>0.05)$ behaviors. In conclusion, the growth performance and behaviors of kids which were raised according to two suckling program were found similar.
\end{abstract}

Key Words: goat kid, growth, behaviour, milk intake

\section{Zusammenfassung}

Titel der Arbeit: Einfluss unterschiedlicher Säugeverfahren auf Wachstumsmerkmale von Saanen Zicklein Die Untersuchungen erfolgten an 21 Einlingsgeborenen Saanen Zicklein im Uvecic Untersuchungs- und Trainingszentrum der Canakkale Onsekiz Mart Universität Die Tiere wurden mit zwei unterschiedlichen Säugeprogrammen aufgezogen. In der ersten Gruppe stand den Tieren jeweils 30 Minuten um 8.00 und 18.00 Uhr das Gesäuge der Mütter zur Verfügung. In der 2. Gruppe wurde die rechte Euterhälfte mit der Hand gemolken und die Zicklein konnten anschließend je 30 Minuten um 8.00 und 18.00 das Euter besaugen. Die Zicklein beider Gruppen wurden nach der 5. Woche abgesetzt. Die Lebendgewichte der Gruppen 1 und 2


$17482,7 \pm 702,8$ g. Diese Unterschiede waren nicht signifikant $(\mathrm{P} \leq 0,05)$ verschieden. Abgesehen von wenigen Ausnahmen konnten keine signifikanten Unterschiede unter anderem bei der Widerristhöhe, dem Brustumfang und weiteren Körpermaßen, der Lebenstagszunahme, der Futter/Wasseraufnahme und einigen Verhaltensmerkmalen festgestellt werden. Zwischen den beiden Gruppen konnten bei den beobachteten Merkmalen keine Unterschiede nachgewiesen werden.

Schlüsselwörter: Ziege, Zicklein, Wachstum, Verhaltensmerkmale, Milchaufnahme

\section{Introduction}

The kids growth is very important in the goat breeding. The kids are the basement of the healthy and producible herds in the future. On the basis of these points, the kids growth methods has a importance. The feeding periods of the kids with milk, starts 
with taking the colostrum just after the birth. After taking the colostrum, different milk drinking program can be applied in kids growing period.

In different studies, the kids growth via applying different milk drinking program were investigated (MORAND-FEHR et al., 1982; SAHLU et al., 1992; LAES-FETTBACK and PETERS, 1995; PETERS and LAES-FETTBACK, 1995; TOUKOUROU and PETERS, 1999). In one study, it was determined that, $25 \%$ of produced milk by the small ruminants was produced in first 30 days of lactation (MCKUSICK et al., 2001). According to this, it is economically very important that kids are fed with a minimum quantity of milk in a minimum period. One of the researchers in this subject, TUNCEL (1995), indicated that, the kids never drink higher than $2 \mathrm{~kg}$ milk in a day. GOETSCH et al. (2001) says, in 3-4 weeks age, the performance of the kids, consume 172 and 117 $\mathrm{g}$ milk dry material in a day, have been found similar between 1-14 weeks. GENANDOY et al. (2002), giving $1 \mathrm{~kg}$ milk into the kids in a day can be accepted as "limited feeding" in kids growing. PALMA and GALINA (1995) and UGUR et al. (2004), indicated, early weaning can be used successfully in kids rearing.

With this study, the best kid raising method, that does not effect negatively the Saanen performance, will give a speed into the milk production of the farms for the selling and its possible to application to the farms, finding was aimed. For this aim, it is giving an permission to suctions of the single born Saanen kids, either, both udder lob which is not used in the milking of their dams, and only one lob of the udder of their dams in the morning and night. The understanding and searching of these applications effect into kids milk consumption, growth and behavioral traits were aimed.

\section{Materials and Methods}

Animal of this study were single born Saanen kids, raised in Canakkale Onsekiz Mart University, Department of Animal Science, Uvecik Yahya Cavus Research Center. In total 21 single born Saanen kids, born in 2004, were used. In this study, 2 different program were used in the kids raising, depends on the suctions by the kids, either 2 udder lob of the dams of the kids (the first program), and only one udder lob of the dams of the kids (the second program). The kids were stayed with their mother for 7 days after the birth. In a 8. day, the kids were separated into this 2 different program, mentioned above. In a separation, it was giving an importance to having a similarities in the animal number, sex proportion and birth weight of the kids, in each groups. According to this, in the first and second program, 11 and 10 kids were placed respectively. The materials, used in kids raising in both 2 program are explained in below.

In a first program, the raised kids, after the separation from their dams in 8. day, were stayed in cage with $6 \mathrm{~m} \times 6 \mathrm{~m} \times 2 \mathrm{~m}$ dimensions. Their dams were not milked. In the morning at 8.00 and in the night at 18.00 o'clock, for 30 minutes the permission were given to suction of the kids. After this period, the kids were removed from their dams. In second program, the raised kids, after the separation from their dams in the 8. day, were stayed in a same dimensions' cage. The right lob of the udder of the dams of the kids, belongs to this program, were milked via hands in the morning and in the night and after that the suckling of the kids were permitted for the 30 minutes in the morning at 8 o'clock and in the night at 18.00 o'clock. After the suckling the kids were removed from their dams. 
The kids raised with both of the program, were weighted before and after the suckling and drank milk quantity were determined (DEGEN and BENJAMIN, 2003). The kids were weaned at 5 weeks age. The study was carried out for 12 weeks. The kids were also offered kid starter and medium quality hay in this period. Roughage and concentrate feed were given ad libitum.

The kids were weighted once a week in a 12 weeks research period and weekly live weight were determined. The live weight of each kids were obtained via using electronic scales ( $\pm 20 \mathrm{~g}$ ) in a research period. With this, height at withers, heart girth and front shank circumference were also determined at 1st, 6th and 12th weeks old . The daily live weight gain of the kids in different time was calculated from weekly live weight.

In this research, some behavioral observations of the kids, raised according to programmed, mentioned above, were done. Behavioral observations were carried out between 2. and 10. weeks. In a study, behavioral traits, described below were monitored and observed.

Concentrate feed consumption: The animal is standing in front of the crib and consumes concentrate feed actively.

Roughage feed consumption: The animal consumes roughage actively.

Water consumption: The kids drink water.

Lying: The kids lying and none of other behaviors are seen.

Standing: The animal is standing and none of other behaviors are seen.

Rumination: The animals are ruminated.

Repeated Measurement Design in Covariance Analysis was used in the statistical analysis of the milk consumption, live weight, height at withers, girth and front shank circumference data of the kids (WINER et al., 1991). The completely randomized factorial experimental design was used in the statistical analysis of the daily live weight gain data. In related analysis, the suction program (application groups) and kids' sex with a fixed effect, the kids' birth weight, their dams' milk yield and their dams' age (month) with a covariant effect, were used. In a analysis of the data, SAS (SAS, 1999) statistical packet program was used.

The observations was made between 10:00-12:00 hours in the morning for 2 hours with 5 minutes gaps via using time-sampling methods and carried out for 8 weeks while the kids stayed in the separate cage. The statistical analysis was done according to GEE (Generalized Estimating Equations) method rules in helping of PROC GENMOD of the SAS (1999) statistical packet program. In this study, the discrete analysis method was used in the determination of the behavioral differences of the kids, raised according to 2 different program and the live weight of the each kid in the monitoring day, the monitoring day and the monitoring time were accepted as the fixed factors as being have a possible effect onto behavioral observations in this analysis method.

\section{Results}

The weekly age milk consumption of the Saanen kids, raised according to the first and second program, were presented in the Table 1 . The difference between the applied suction program on the basis of the milk consumption of the kids in the first, second and fifth weeks were obtained statistically n.s. In contrast to this, the milk 
consumption in the third $(\mathrm{P} \leq 0.01)$ and fourth $(\mathrm{P} \leq 0.05)$ weeks were found different according to the programs.

Table 1

Least squares means and their standard errors for milk consuming (g) (LS-Mittelwerte und deren Standardfehler für die Milchaufnahme)

\begin{tabular}{|c|c|c|c|c|c|c|}
\hline \multirow[b]{3}{*}{ Weeks: } & \multicolumn{3}{|c|}{ Program } & \multicolumn{3}{|c|}{ Gender } \\
\hline & $\begin{array}{c}\text { The First } \\
\mathrm{n}=11\end{array}$ & $\begin{array}{c}\text { The Second } \\
\mathrm{n}=10\end{array}$ & $\mathrm{P}$ & $\begin{array}{c}\text { Female } \\
\mathrm{n}=11\end{array}$ & $\begin{array}{l}\text { Male } \\
n=10\end{array}$ & $\mathrm{P}$ \\
\hline & $\bar{x} \pm S_{\bar{x}}$ & $\bar{x} \pm S_{\bar{x}}$ & & $\bar{x} \pm S_{\bar{x}}$ & $\bar{x} \pm S_{\bar{x}}$ & \\
\hline 1. & $1071.6 \pm 77.9$ & $1036.0 \pm 81.1$ & n.s. & $1086.0 \pm 81.4$ & $1021.6 \pm 77.9$ & $\overline{\text { n.s. }}$ \\
\hline 2. & $1493.0 \pm 130.5$ & $1294.0 \pm 136.4$ & n.s. & $1462.0 \pm 136.4$ & $1325.0 \pm 130.5$ & n.s. \\
\hline 3. & $1754.6 \pm 101.1$ & $1346.0 \pm 106.1$ & $* *$ & $1578.0 \pm 106.1$ & $1522.6 \pm 101.6$ & n.s. \\
\hline 4. & $1696.1 \pm 99.1$ & $1345.0 \pm 103.5$ & * & $1529.0 \pm 103.5$ & $1512.1 \pm 99.1$ & n.s. \\
\hline 5. & $1735.3 \pm 130.7$ & $1382.0 \pm 136.5$ & n.s. & $1526.0 \pm 136.5$ & $1591.3 \pm 130.7$ & n.s. \\
\hline
\end{tabular}

The least square means and standard error of the means of the live weight and body measurements belongs to the Saanen kids, raised according to the first and second program, were given in the Table 2 and 3, respectively. In the first 5 weeks period, the effect of the applied program into the weekly live weight of the kids was obtained statistically n.s. The similar patterns continued after the fifth weeks. In generally, it was found that, the males have higher means compare to the females, when you looked at the Saanen kids' weekly live weight changes according to the sexes in Table 2.

Table 2

Least squares means and their standard errors for weights (g) (LS-Mittelwerte und deren Standardfehler für die Lebendgewichte)

\begin{tabular}{|c|c|c|c|c|c|c|}
\hline & \multicolumn{3}{|c|}{ Program } & \multicolumn{3}{|c|}{ Gender } \\
\hline & $\begin{array}{c}\text { The First } \\
\mathrm{n}=11 \\
\bar{x} \pm S_{\bar{x}}\end{array}$ & $\begin{array}{l}\text { The Second } \\
\qquad \begin{array}{c}\mathrm{n}=10 \\
\bar{x} \pm S_{\bar{x}}\end{array}\end{array}$ & $\mathrm{P}$ & $\begin{array}{c}\text { Female } \\
\mathrm{n}=11 \\
\bar{x} \pm S_{\bar{x}}\end{array}$ & $\begin{array}{c}\text { Male } \\
\mathrm{n}=10 \\
\bar{x} \pm S_{\bar{x}} \\
\end{array}$ & $\mathrm{P}$ \\
\hline \multicolumn{7}{|l|}{ Weeks: } \\
\hline 1. & $5588.4 \pm 133.4$ & $5381.1 \pm 138.7$ & n.s. & $5584.2 \pm 138.2$ & $5385.3 \pm 132.2$ & n.s. \\
\hline 2. & $6578.7 \pm 196.5$ & $6509.7 \pm 204.2$ & n.s. & $6552.2 \pm 203.5$ & $6336.2 \pm 194.6$ & n.s. \\
\hline 3. & $8082.0 \pm 199.1$ & $7692.4 \pm 206.9$ & n.s. & 7939.1 \pm 206.2 & 7835.3 \pm 197.2 & n.s. \\
\hline 4. & $9633.3 \pm 224.1$ & $8957.6 \pm 233.4$ & n.s. & $9237.0 \pm 232.6$ & $9353.9 \pm 222.7$ & n.s. \\
\hline 5. & $10963.0 \pm 274.4$ & $10384.9 \pm 285.1$ & n.s. & $10453.6 \pm 284.2$ & $10894.8 \pm 271.7$ & n.s. \\
\hline 6. & $12205.5 \pm 207.5$ & $11825.3 \pm 215.6$ & n.s. & $11624.2 \pm 216.9$ & $12406.6 \pm 205.5$ & $*$ \\
\hline 7. & $13021.1 \pm 291.7$ & $12671.2 \pm 303.1$ & n.s. & $12709.5 \pm 302.1$ & $12983.1 \pm 288.9$ & n.s. \\
\hline 8. & $13877.7 \pm 408.2$ & $13517.3 \pm 424.1$ & n.s. & $13587.6 \pm 422.8$ & $13806.8 \pm 416.5$ & n.s. \\
\hline 9. & $14891.3 \pm 420.5$ & $14236.2 \pm 436.9$ & n.s. & $14566.0 \pm 435.5$ & $14561.5 \pm 416.5$ & n.s. \\
\hline 10. & $15980.2 \pm 477.9$ & $15137.7 \pm 496.6$ & n.s. & $15462.4 \pm 495.6$ & $15655.6 \pm 473.3$ & n.s. \\
\hline 11. & $17274.8 \pm 214.3$ & $17084.9 \pm 214.3$ & n.s. & $17136.6 \pm 257.8$ & $17323.1 \pm 202.8$ & n.s. \\
\hline 12. & $17932.9 \pm 676.3$ & $17482.7 \pm 702.8$ & n.s. & $17482.7 \pm 700.6$ & $17932.3 \pm 669.9$ & n.s. \\
\hline
\end{tabular}

n.s.: not significant

*: $\mathrm{P} \leq 0.05$

But the live weight differences, being beneficial in males, were found statistically n.s. The effect of the applied suckling program into the girth were significant $(\mathrm{P} \leq 0.05)$ in 6 th and 12th weeks, while in other times were n.s. (Table 3). 
Table 3

Least squares means and their standard errors for height at withers (cm), heart girth (cm) and front shank circumference $(\mathrm{cm})$ (LS-Mittelwerte und deren Standardfehler für die Wideristhöhe, Brustumfang und Vorderbeinschenkelumfang)

\begin{tabular}{|c|c|c|c|c|c|c|}
\hline & \multicolumn{3}{|c|}{ Program } & \multicolumn{3}{|c|}{ Gender } \\
\hline & $\begin{array}{c}\text { The First } \\
\mathrm{n}=11 \\
\bar{X} \pm S_{\bar{x}}\end{array}$ & $\begin{array}{l}\text { The Second } \\
\begin{array}{c}\mathrm{n}=10 \\
\bar{x} \pm S_{\bar{x}}\end{array}\end{array}$ & $\mathrm{P}$ & $\begin{array}{c}\text { Female } \\
\mathrm{n}=11 \\
\bar{x} \pm S_{\bar{x}}\end{array}$ & $\begin{array}{c}\text { Male } \\
\mathrm{n}=10 \\
\bar{x} \pm S_{\bar{x}}\end{array}$ & $\mathrm{P}$ \\
\hline \multicolumn{7}{|l|}{ 1st week: } \\
\hline Height at withers & $36.8 \pm 0.6$ & $37.3 \pm 0.7$ & n.s. & $36.8 \pm 0.7$ & $37.1 \pm 0.6$ & n.s. \\
\hline Heart girth & $39.5 \pm 0.5$ & $38.6 \pm .0 .6$ & n.s. & $39.1 \pm 0.6$ & $39.0 \pm 0.5$ & n.s. \\
\hline $\begin{array}{l}\text { Front shank circumference } \\
\text { 6th week: }\end{array}$ & $7.4 \pm 0.2$ & $7.8 \pm 0.1$ & $\begin{array}{l}\text { n.s. } \\
\text { n.s. }\end{array}$ & $7.5 \pm 0.2$ & $7.7 \pm 0.2$ & $\begin{array}{l}\text { n.s. } \\
\text { n.s. }\end{array}$ \\
\hline Height at withers & $49.2 \pm 0.6$ & $47.5 \pm 0.6$ & n.s. & $47.6 \pm 0.6$ & $49.2 \pm 0.6$ & n.s. \\
\hline Heart girth & $56.3 \pm 0.6$ & $53.9 \pm 0.8$ & $*$ & $55.0 \pm 0.7$ & $55.2 \pm 0.6$ & n.s. \\
\hline $\begin{array}{l}\text { Front shank circumference } \\
\text { 12th week: }\end{array}$ & $8.4 \pm 0.1$ & $8.1 \pm 0.1$ & $\begin{array}{l}\text { n.s. } \\
\text { n.s. }\end{array}$ & $8.4 \pm 0.2$ & $8.1 \pm 0.2$ & $\begin{array}{l}\text { n.s. } \\
\text { n.s. }\end{array}$ \\
\hline Height at withers & $51.7 \pm 0.9$ & $51.1 \pm 0.9$ & n.s. & $51.1 \pm 0.9$ & $51.6 \pm 0.9$ & n.s. \\
\hline Heart girth & $61.1 \pm 0.8$ & $58.5 \pm 0.8$ & $*$ & $60.0 \pm 0.8$ & $59.6 \pm 0.9$ & n.s. \\
\hline Front shank circumference & $8.4 \pm 0.1$ & $8.4 \pm 0.1$ & n.s. & $8.1 \pm 0.1$ & $8.6 \pm 0.1$ & $* *$ \\
\hline
\end{tabular}

significant

*: $\mathrm{P}<0.05$

$* *: \mathrm{P} \leq 0.01$

The observed differences, on the basis of the searched body measurements, between different sex groups were found statistically n.s. The least square means and standard errors of the means of the daily weight gain were presented in the Table 4. In according to the Table 4, the effect of the programs into the daily weight gain was found statistically n.s. after the 5 weeks period.

Table 4

Least squares means and their standard errors for daily weight gains (g) (LS-Mittelwerte und deren Standardfehler für tägliche Zunahme)

\begin{tabular}{|c|c|c|c|c|c|c|}
\hline & \multicolumn{3}{|c|}{ Program } & \multicolumn{3}{|c|}{ Gender } \\
\hline & $\begin{array}{c}\text { The First } \\
\mathrm{n}=11 \\
\bar{x} \pm S_{\bar{x}}\end{array}$ & $\begin{array}{l}\text { The Second } \\
\qquad \begin{array}{c}\mathrm{n}=10 \\
\bar{x} \pm S_{\bar{x}}\end{array}\end{array}$ & $\mathrm{P}$ & $\begin{array}{c}\text { Female } \\
\mathrm{n}=11 \\
\bar{x} \pm S_{\bar{x}}\end{array}$ & $\begin{array}{c}\text { Male } \\
\mathrm{n}=10 \\
\bar{x} \pm S_{\bar{x}}\end{array}$ & $\mathrm{P}$ \\
\hline \multicolumn{7}{|c|}{$\begin{array}{l}\text { Periods } \\
\text { (week) }\end{array}$} \\
\hline $1-3$ & $178.2 \pm 11.2$ & $178.2 \pm 11.2$ & n.s. & $168.3 \pm 11.6$ & $175.0 \pm 11.1$ & n.s. \\
\hline $1-5$ & $192.0 \pm 9.5$ & $178.6 \pm 9.9$ & n.s. & $173.8 \pm 9.8$ & $196.8 \pm 9.4$ & n.s. \\
\hline $2-5$ & $208.7 \pm 13.2$ & $184.5 \pm 13.7$ & n.s. & $185.1 \pm 13.7$ & $207.5 \pm 13.1$ & n.s. \\
\hline $1-8$ & $169.1 \pm 7.8$ & $165.9 \pm 8.1$ & n.s. & $163.1 \pm 8.1$ & $171.8 \pm 7.7$ & n.s. \\
\hline $5-6$ & $177.4 \pm 22.0$ & $205.8 \pm 22.8$ & n.s. & $167.2 \pm 22.8$ & $216.0 \pm 21.8$ & n.s. \\
\hline $1-12$ & $160.2 \pm 8.4$ & $157.0 \pm 8.7$ & n.s. & $154.5 \pm 8.7$ & $162.8 \pm 8.3$ & n.s. \\
\hline $5-12$ & $142.2 \pm 10.5$ & $144.7 \pm 10.9$ & n.s. & $143.3 \pm 10.9$ & $143.5 \pm 10.4$ & n.s. \\
\hline $8-12$ & $144.1 \pm 12.9$ & $141.5 \pm 13.4$ & n.s. & $139.1 \pm 13.5$ & $147.1 \pm 12.8$ & n.s. \\
\hline
\end{tabular}

The regression coefficient, standard errors and odds ratios of the observed behavioral traits were given in the Table 5. The statistically n.s. differences were found between the roughage consumption of the different programs, but the kids of the first program displayed this behavior $2 \%$ less then the second group kids $(\psi=0.98)$. In similarly, 32\% less in concentrate feed consumption $(\psi=0.68), 21 \%$ less in water consumption $(\psi=0.79), 16 \%$ less in lying $(\psi=0.84)$, and $28 \%$ less in ruminations $(\psi=0.72)$ were seen in the first program kids. The 
standing behaviors were displayed $103 \%$ higher in first program kids, and the differences were found statistically significant $(\mathrm{P} \leq 0.001)$.

Table 5

Regression coefficients (b), standard errors (SE) and odds ratios ( $\psi$ ) of the behavioral traits $\underline{\text { (Regressionskoeffizienten (b), Standardfehler (SE) und relatives Chancenverhältnis ( } \psi \text { ) für Verhaltensmerkmale) }}$

\begin{tabular}{lcccc}
\hline Behavioral traits: & $\mathrm{b}$ & $\mathrm{SE}$ & $\Psi$ & $\mathrm{P}$ \\
\hline Roughage intake & -0.02 & 0.17 & 0.98 & $\mathrm{n} . \mathrm{s}$. \\
Concentrate intake & -0.38 & 0.26 & 0.68 & n.s. \\
Water intake & -0.23 & 0.35 & 0.79 & n.s. \\
Lying & -0.17 & 0.25 & 0.84 & n.s. \\
Rumination & -0.32 & 0.41 & 0.72 & n.s. \\
Standing & 0.71 & 0.21 & 2.03 & $* * * *$ \\
\hline
\end{tabular}

Odds ratio $(\psi)$ is 1.00 for second program.

n.s.: not significant

$* * *: \mathrm{P} \leq 0.001$

\section{Discussion}

In this study, the daily milk consumption of the kids, raised according to the second program, were determined as $1273.2 \pm 65.9 \mathrm{~g}$ in the first 5 weeks period. The similar milk consumption values were obtained also by PETERS and LAES-FETTBACK, 1995; LUO et al. (2000), FERREIRA and THORNTON (2004) and AYISIGI et al. (2005).

The live weights of the kids in the 5 th weeks were found as $10963.0 \pm 274.4 \mathrm{~g}$ for the first program and 10384.9 $\pm 285.1 \mathrm{~g}$ for the second program. PALMA and GALINA (1995) and PALA et al. (2005), were indicated that Saanen kids can be weaned successfully when they reached $10 \mathrm{~kg}$ live weight. LU and POTCHOIBA (1988), indicated the kids can be weaned at when they reached $9 \mathrm{~kg}$ live weight. According to these findings, the kids, raised on basis of the two program within this study, reached weaning maturation at 5 th weeks.

MISHRA (1976) indicated that the kids should consume $10 \%-20 \%$ of live weights milk in day. It is possible to calculate weekly milk consumption rate depends on the live weights of the kids, raised within this study. The weekly milk consumption rate according to the their live weights of the kids were determined from daily milk consumption in Table 1 and live weight data in Table 2 [(daily milk consumption / live weights) $\times 100$ ]. According to this, the milk consumption were 19\%, 23\%, 22\%, 17\% and $16 \%$ of their live weights of the first program kids in the $1^{\text {st }}$ to $5^{\text {th }}$ weeks respectively. The similar rates for the second program kids were 19\%, 20\%, 17\%, 15\% and $13 \%$ of their live weights respectively. As mentioned before, the live weights, reached in the 5th weeks, were similar in two programs' kids. In this situation, the milk consumption were 19\%, 20\%, 17\%, 15\% and 13\% of the live weights of the kids, raised according to the second program, in the $1^{\text {st }}$ to $5^{\text {th }}$ weeks respectively and it is possible to conclude as they reached the enough weaning maturation via reaching 10 $\mathrm{kg}$ live weights in the end of the 5th weeks.

The daily weight gain data of the kids were presented in the Table 3 . The daily weight gain between 1-5 weeks was found statistically n.s. but first group got numeratical advantages compare to the second group. This finding is normal. Because, the first group kids consumed much higher milk (Table 1), causing to the higher daily weight gain means in this group. In later weeks this differences ended. For example, the daily

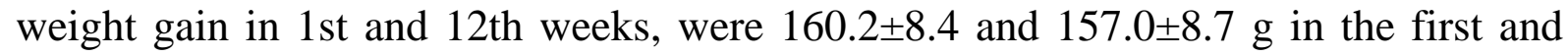


second groups, respectively. At the 5th and 6th weeks daily weight gains, the second group kids have an numeratical advantages compare to the first group kids. These advantages were not found statistically significant. This result indicating, either the roughage feed consumption of the kids, consume much lower milk, were encouraged or these animals learned the roughage feed consumption behavior much earlier then the others. The kids, learned much earlier roughage feed consumption, were consumed much enough feed after the weaning period. This finding, cause the kids pass the critical weaning period in a more comfortable situation. Also, the live weights, daily weigh gains, height at withers, heart girth and front shank circumference datas of the second group kids were similar to the indicated datas of the Saanen, can be told (LAES-FETTBACK and PETERS, 1995; PETERS and LAES-FETTBACK, 1995; TOUKOUROU and PETERS, 1999; UGUR et al., 2004; FERREIRA and THORNTON, 2004; AYISIGI et al., 2005).

The suckling program effect into the some behavioral traits as a stress indicator is important as well as into the growth traits. Apart from the nutritional requirements of animals, there are behavioral requirements, which have not been well investigated (SMIDT et al., 1995). In this study, the effect of the applied two suckling program into kids' some behavioral traits were searched. In a study, concentrate feed consumption, roughage consumption, water consumption, lying, standing and rumination behaviors were searched. According to the Table 5, the first group of kids displayed concentrate feed, roughage feed, the water, lying, standing and rumination behaviors much less compare to the second group of kids. This finding is normal. Because, the first group of kids' daily milk consumption is higher then the second program (Table 1). The higher milk consumption could be limitized the concentrate and roughage feed consumption. In a similarly, it could be seen less water consumption in a kids, consume higher milk. The first group of kids consume higher milk, compare to the second group and they spend much time in a standing position, according to the Table $5(\mathrm{P} \leq 0.001)$. This situation can be explained as the higher milk consumption causing a decrease in the roughage feed consumption behavior and its speed. The first group kids less ruminated then the second program kids. The less roughage and concentrate feed consumption and together this, less water consumption of the first group of kids could be caused to their less rumination. According to this, the less milk consumption could be stimulated the roughage feed consumption in the kids. The similar indications were made by LU and POTCHOIBA, (1988), DAVIS et al. (1998), TOUKOUROU and PETERS, (1999) and UGUR et al. (2004).

As a result of that, the performance values of the single-born Saanen kids, suckled the right lob of the udder of the kid's dams twice in the night and in the morning for 30 min for 5 weeks, were found similar to the literature datas of the same breed. The kids, raised according to these programs, consumption 19\%, 20\%, 17\%, $15 \%$ and $13 \%$ of their live weight milk in the 1st, 2nd, 3rd, 4th and 5th weeks respectively, and they have reached the weaning maturation in the end of the 5 weeks via reaching $10 \mathrm{~kg}$ live weight. 


\section{References}

AYISIGI, K.; ATASOGLU, C.; YURTMAN, İ.Y.; MENDES, M.; PALA, A.:

Effect of probiotic supplementation shortly before and after weaning on growth of Turkish Saanen kids. Arch. Tierz., Dummerstorf 48 (2005), 601-611

DAVIS, J.J.; SAHLU, T.; PUCHALA, R.; TESFAI, K.: Performance of Angora goat kids fed acidified milk replacer at two levels of intake. Small Rum. Res. 28 (1998), 249-255

DEGEN, A. A.; BENJAMIN, R. W.:

Milk intake and growth rate of Awassi lambs sucking ewes grazing on natural pasture in the semi - arid Negev. Anim. Sci. 76 (2003), 455-460

FERREIRA, A.V.; THORNTON, J.D: Feed intake and growth of Saanen kids weaned at 42 and 70 days of age. South African J. Anim. Sci. 34 (2004), 49-51

GENANDOY, H.; SAHLU, T.; DAVIS, J.; WANG, R.J.; HART, S.P.; PUCHALA, R.; GOETSCH, A.L: Effects of different feeding methods on growth and harvest traits of young Alpine Kids. Small Rumin. Res. 44 (2002), 81-87

GOETSH, A.L.; DETWEILER, G.; SAHLU, T.; DAWSON, L. J.: Effects of different managment practices on preweaning and early postweaning growth of Alpine kids. Small Rumin. Res. 41 (2001), 109-116.

LUO, T.; SAHLU, T.; CAMERON, M.; GOETSH, A. L:

Growth of Spanish, Boer x Angora and Boer x Spanish goat kids feed milk replacer. Small Rumin. Res. 36 (2000), 189-194

LAES-FETTBACK, C.; PETERS, K.J.:

A Comparative-study of performance of Egyptian goat breeds. 2. Growth performance and productivity, Arch. Tierz., Dummerstorf 38 (1995), 563-575

LU, C.D.; POTCHOIBA, M.J.:

Milk feeding and weaning of goat kids a review. Small Rumin. Res. 18 (1988), 105-112

MISHRA, R.R.:

Management Practices for Goats. National Dairy Research Institute.Publication no: 147 (1976), Karnal (Haryana).

MCKUSICK, B.C.; THOMAS, D.L.; BERGERT, Y.M.:

Effect of weaning system on commercial milk production and lamb growth of East Friesian dairy sheep. J. Dairy Sci. 84 (2001), 1660-1668

MORAND-FEHR, P.; HERVIEU, J.; BAS, P.; SAUANT, D.:

Feeding of young goats. Proceedings of Third International Conference on Goat Production and Disease. Tucson, Arizona, USA (1982), 90-104

PALA, A.; SAVAS, T.; UGUR, F.; DAS, G.:

Growth curves o Turkish Saanen Goats' kids grouped for weight and body mass index. Arch. Tierz., Dummerstorf 48 (2005), 185-193

PALMA, J.M.; GALINA, M.A.:

Effect of early and late weaning on the growth of female kids. Small Rumin. Res. 18 (1995), 33-38

PETERS K.J.; LAES-FETTBACK C.:

A comparative-study of performance of Egyptian goat breeds .1. Reproductive and dairy performance. Arch. Tierz., Dummerstorf 38 (1995), 93-102

SAS ${ }^{\circledR}:$

SAS Institute Inc., SAS OnlineDoc ${ }^{\circledR}$, Version 8, Cary, NC, USA, (1999).

SAHLU, T.; CARNERIO, H.; EL SHAER, H.M.; FERNANDEZ, J.M.:

Production performance and physiological responses of Angora goat kids feed acidified milk replacer. J. Dairy Sci. 75 (1992), 1643-1650

SMIDT, D.; SCHLICHTING, M.C.; LADEWIG, J.; STEINHARDT, M.:

Ethologische und verhaltensphysiologische Forschung für tiergerechte Nutztierhaltung. Arch. Tierz., Dummerstorf 38 (1995), 7-19.

TOUKOUROU, Y.; PETERS K.J.:

Auswirkungen restriktiver Ernährung auf die Wachstumsleistung von Ziegenlämmern. Arch. Tierz., Dummerstorf 42 (1999), 281-293

TUNCEL, E.:

Küçükbas Hayvan Yetistirme. Uludag Univ. Ziraat Fak. Ders Notları No: 23 (1995), Bursa.

UGUR, F.; SAVAS, T.; DOSAY, M.; KARABAYİR, A.; ATASOGLU, C.:

Growth and Behavioral Traits of Turkish Saanen Kids Weaned at 45 and 60 days. Small Rumin. Res. 52 (2004), 179-184 
WINER, B.J.; BROWN, D.R.; MICHELS, K.M.:

Statistical Principles in Experimental Design. McGraw-Hill Inc. (1991), 1057

Received: 2006-07-10

Accepted: 2007-07-25

Authors' addresses

MSc. FIGEN DIKEN

Department of Animal Science, Faculty of Agriculture, Canakkale Onsekiz Mart

University, 17020, CANAKKALE / TURKEY

Assoc. Prof. Dr. FEYZI UGUR

Department of Animal Science, Faculty of Agriculture, Canakkale Onsekiz Mart

University, 17020, CANAKKALE / TURKEY (E-mail: fugur@comu.edu.tr)

Res. Assist. CEMIL TOLU

Department of Animal Science, Faculty of Agriculture, Canakkale Onsekiz Mart University, 17020, CANAKKALE / TURKEY) (E-mail: cemiltolu@comu.edu.tr)

Assist. Prof. Dr. MINE DOSAY AKBULUT*

Deparment of Medical Biology and Genetics, Faculty of Veterinary Medicine, Kocatepe University, AFYONKARAHISAR / TURKEY

* Corresponding author

E-mail: minedosay@hotmail.com 